\title{
Clare Gerada: Doctors deserve to work in an environment that doesn't make them sick
}

\author{
Clare Gerada GP partner
}

Hurley Group, London

I recently had a big birthday, one that allows me to have a free London bus pass. This milestone has caused me to reflect on my long career, particularly my work with the NHS.

I've mentioned before that I started working in the NHS at 14. Initially I worked on Saturdays in a local pharmacy before becoming the Saturday morning receptionist at my father's singlehanded general practice. To spare you the maths, I've now been involved with the NHS for 46 years-a long time by anyone's standards. I want to continue to work and have no intention of hanging up my stethoscope, although I'm grateful to my partners that I'll no longer have to do out-of-hours work.

There have, of course, been difficult times over the years, when I've been burnt out-depressed even-and needed to take time out from frontline clinical practice. But, overall, I've enjoyed each day and feel grateful for having had such a valuable and enriching career.

I've been lucky. Over the course of my career I've mostly been able to have autonomy in my working life. I've also had a deep sense of belonging to the various teams I've worked with, and I've generally felt competent in the jobs I've done. Autonomy, belonging, and competence ( $\mathrm{ABC}$ ) are the three prerequisites for wellbeing identified by Michael West in his excellent recent publication Caring for Doctors, Caring for Patients. ${ }^{12}$ This independent report was commissioned by the General Medical Council in response to the crisis of wellbeing and poor mental health among NHS doctors.

West's report is long but worth reading. Autonomy is the need to have control over our working lives and to be able to act consistently with our work and life values. Belonging, a universal human need, is the desire to be connected and cared for and to feel valued, respected, and supported. Competence is not just having the paper qualifications but feeling confident in what we do and in being able to deliver the outcomes we were trained to.

I really hope that the recommendations in West's report are implemented. If so, they'll go a long way to tackling the problems we have with recruitment and, more importantly, retention. They would also improve wellbeing and motivation at work and minimise workplace stress.

Today's doctors deserve to work in an environment that doesn't make them sick. Moreover, they have a right not just to survive in their work but to thrive, as I have. Policy makers and politicians now have an ethical and moral responsibility to make the NHS the best place in the world to work.

Competing interests: See www.bmj.com/about-bmj/freelance-contributors. Provenance and peer review: Commissioned; not externally peer reviewed.

1 West M, Coia D. Caring for doctors, caring for patients: how to transform UK healthcare environments to support doctors and medical students to care for patients. General Medical Council. Nov 2019. https://www.gmc-uk.org/-/media/documents/caring-for-doctors-caringfor-patients_pdf-80706341.pdf.

2 Rimmer A. Doctors' wellbeing: GMC promises action. BMJ 2019;367:16484. 10.1136/bmj.16484 31732488

Published by the BMJ Publishing Group Limited. For permission to use (where not already granted under a licence) please go to http://group.bmj.com/group/rights-licensing/ permissions 